ROCZNIKI KULTUROZNAWCZE

Tom X, numer $2 \quad-\quad 2019$

DOI: http://dx.doi.org/10.18290/rkult.2019.10.2-2

ZUZANNA WNUK

\title{
„TO, CZEGO NIE MOŻNA ZMIENIĆ, MOŻNA JEDYNIE CIERPLIWIE ZNOSIĆ": „SKŁADAJĄCY SIĘ PEKIN” HAO JINGFANG JAKO METAFORA ROZWARSTWIONEGO SPOŁECZEŃSTWA
}

Obraz Pekinu przyszłości oraz rozwarstwionego społeczeństwa uwięzionego w stanie nieustannej zmiany i bezosobowym mieście molochu wykreowany przez Hao Jingfang (郝景芳, Hăo Jǔngfāng) ${ }^{1}$ w „,Składającym się Pekinie"2 (北京折叠, Běijīng zhédié) może być odczytany jako refleksja na temat problemów współczesności, takich jak nieprzekraczalność barier społecznych, spetryfikowany system klasowo-warstwowy czy też rozwój technologiczny, który czyni ludzi zbędnymi. Przez zastosowanie technik charakterystycznych dla science fiction - takich jak na przykład defamilaryzacja kognitywna $^{3}$ - oraz poruszanie wątków typowych dla tej literatury — na przykład motywu utopii czy też wpływu rozwoju technologicznego na

Mgr ZuZanna WnuK - Uniwersytet im. Adama Mickiewicza, Wydział Neofilologii, Katedra Orientalistyki; adres do korespondencji — e-mail: wnuk.zuzanna@gmail.com; ORCID: https://orcid.org/0000-0002-5883-7917.

${ }^{1}$ Imiona i nazwiska chińskie zapisane są w odwrotnej kolejności, to znaczy najpierw nazwisko, a potem imię, zgodnie z ogólnie przyjętą konwencją. Wszystkie chińskie nazwy własne pojawiające się w tekście po raz pierwszy zostały opatrzone znakami oraz zapisem fonetycznym według transkrypcji hanyu pinyin $\mathrm{w}$ nawiasie okrągłym. Nazwy oryginalne terminów zaczerpniętych ze źródeł angielskojęzycznych i chińskojęzycznych zostały podane w nawiasach kwadratowych przy ich pierwszym pojawieniu się w tekście.

${ }^{2}$ HǍo Jungfāng, „Běijīng Zhédié” [Składający się Pekin], dostęp 12.06.2017, http://jessicahjf.lofter.com/post/ 1d118899_60d4821?act=qbbloglofter_20150506_01.

${ }^{3}$ Według Darko Suvina defamiliaryzacja kognitywna polega na zmuszeniu czytelnika do zastanowienia się i dostrzeżenia na nowo złożoności świata poprzez wprowadzenie do świata przedstawionego elementów nieznanych i jednocześnie prawdopodobnych. Perry NoDELMAN. „The Cognitive Estragement of Darko Suvin" [Defamiliaryzacja kognitywna Darko Suvina], Children's Literature Association Quaterly [Kwartalnik Stwowarzyszenia Literatury Dziecięcej] 5 (1981), 4: 24-27. 
życie człowieka - opowiadanie to może zostać zaklasyfikowane jako science fiction ${ }^{4}$.

Science fiction, tradycyjnie postrzegane jako literatura dziecięca bądź też stygmatyzowane jako literatura niskich lotów, i to zarówno w Chinach, jak i na Zachodzie, dopiero niedawno zaczęło być szerzej omawiane i analizowane ${ }^{5}$; perspektywa badaczy i pisarzy zmieniła się - Ursula K. Le Guinn nazwała science fiction „współczesną mitologią"6, Wu Yan (吴岩, Wú Yán) zwraca uwagę także na to, że science fiction pomaga mierzyć się z posthumanizmem i potrafi ukazać istotę postczłowieka ${ }^{7}$. Podobnego zdania jest Jean Baudrillard, filozof i socjolog należący do nurtu postmodernistycznego. Według niego tylko science fiction jest w stanie dać współczesnemu kulturoznawcy aparat pojęciowy niezbędny do opisania tego, co aktualnie się dzieje $^{8}$. Wymienia trzy typy science fiction. Pierwszy to ten utopijny, przedstawiający obraz idealnej rzeczywistości wywodzącej się ze współczesnych realiów i stanowiącej realizację marzeń społeczeństwa, która jest jednocześnie krytykowana. Do drugiego rodzaju zaliczane jest klasyczne science fiction ze „złotego okresu” drugiej połowy XX wieku, gdy pisarze używali ekstrapolacji i wyobrażeń dotyczących rozwoju nauki, by tworzyć wizje przyszłości, która miała być podobna do „teraz”, tyle że „zintensyfikowana”. Intensyfikacji podlegały pozytywne i negatywne cechy współczesnego społeczeństwa i świata będące podstawą do rozważań. Trzeci typ to „science fiction czasu symulakr", wedle Baudrillarda jest jedynym sposobem, by opisać współczesność: „w dzisiejszym świecie zanikło rozróżnienie między rzeczami a ich odwzorowaniami, nie ma już prawdy i fikcji, ale istnieje jedna przestrzeń, w której przenikają się rozmaite teksty, kopie i przedstawienia pseudofaktów. Pewien rodzaj science fiction jest w stanie dzięki swojej poetyce ukazać taki świat modeli i iluzji, których nie można zweryfikować, by

\footnotetext{
${ }^{4}$ Utwór science fiction powinien spełniać następujące kryteria: być literacki (interesujący, absorbujący, prowokujący do myślenia, z humorem), eksploracyjny (badawczy, dotyczyć przyszłości), naukowy (naukowy charakter, zawiera prognozy przyszłości), poznawczy (dziwny, niezwykły, intrygujący), estetyczny (nowatorski, ze świeżym spojrzeniem) i ostrzegawczy (przerażający). Wú Yán, „Lùn kēhuàn xiăoshuō de găiniàn” [O pojęciu science fiction], Künmíng Shïfàn Gāodèng Zhuănkē Xuéxiào Xuébào [Czasopismo Uniwersytetu Kunming] 26 (2004), 1: 5-9.

${ }^{5}$ Edward James i Farah Mendessohn, The Cambridge Companion to Science Fiction [Niezbędnik Cambridge do science fiction] (New York: Cambridge University Press, 2003) oraz David SEed, Science Fiction: A very short introduction [Science fiction. Bardzo krótkie wprowadzenie] (New York: Oxford University Press, 2011).

${ }^{6}$ Brian BAKER, Science Fiction (London: Palgrave, 2014), 58.

${ }^{7}$ Wú, „Lùn kēhuàn”, 9.

${ }^{8}$ Dominika Oramus, O pomieszaniu gatunków: Science fiction a postmodernizm (Warszawa: Wydawnictwo „Trio”, 2010), 12.
} 
odkryć ukrytą prawdę o świecie — gdyż jedyną prawdą jest odwzorowanie i inscenizowanie faktów"".

Joan Goron i Veronica Hollinger definiują postmodernizm jako zjawisko dotyczące ludzkiego postrzegania czasu. Według nich „w kategoriach temporalno-psychologicznych jest to świadomość, że cywilizacja znajduje się w bliżej nieokreślonym miejscu między teraźniejszością a przyszłością. Opisać je można jedynie w kategoriach fantastycznych, gdyż dzięki science fiction udaje się tworzyć znaki, których desygnaty jeszcze nie istnieją"10. Natomiast David Punter zauważa, że ,współczesna literatura popularna stworzyła język pozwalający mówić o traumach końca XX wieku: dehumanizacji, późnym kapitalizmie z jego przesadnym marketingiem, chaosie informacyjnym, maltretowaniu dzieci, seryjnych zabójcach, zatruciu środowiska" ${ }^{11}$. Współcześnie science fiction może więc zostać uznane za środek wyrażania refleksji nad stanem współczesności - przede wszystkim w kontekście społecznym i kulturowym. W Chinach zaś science fiction stało się środkiem dla wyrażenia tego, czego nie była w stanie wyrazić literatura głównego nurtu — wskazuje na to chociażby Chen Qiufan (陈楸帆, Chén Qiūfān) ${ }^{12}$.

W ostatnich latach w Chinach nastąpił gwałtowny wzrost zainteresowania science fiction - w porównaniu do trzydziestu pięciu pozycji wydanych w 2000 r., w 2016 r. było ich aż sto cztery; znacznie zwiększyła się także liczba publikowanych opowiadań: w 2011 r. było ich sto dziewięćdziesiąt sześć, w 2015 r. trzysta sześćdziesiąt dwa, a w 2016 r. czterysta sześćdziesiąt jeden. Dane te pokazują, jak prężnie w ostatnich latach rozwija się science fiction w Chinach, natomiast przyznane w 2015 i 2016 r. prestiżowe nagrody Hugo chińskim pisarzom oraz liczne thumaczenia ich utworów na język angielski pokazują wzrost zainteresowania chińskim science fiction na świecie ${ }^{13}$. Łączy się to $\mathrm{z}$ twórcami nazwanymi Nowym Pokoleniem chińskiego science fiction, które narodziło się dzięki szerokim dyskusjom i polemikom dotyczącym tego gatunku, jakie miały miejsce pod koniec lat 80 . W Chinach. Zapoczątkowało to "złotą erę” chińskiego science fiction, która

\footnotetext{
${ }^{9}$ Ibid., 12; Jean BAUDRILLARD, Symulakry i symulacja, przeł. Sławomir Królak (Warszawa: Sic!, 2005), 149-156.

${ }^{10}$ Oramus, O pomieszaniu gatunków, 10.

${ }^{11}$ Ibid., 13.

${ }^{12}$ RÈN Dōngméi, „Cóng kēhuàn xiànshí zhǔyì jiăodù jiědú Běijīng Zhédié” [Odczytanie „Składającego się Pekinu” z punktu widzenia realizmu science fiction], Nánfāng Wéntán [Południowe Forum Literatury] 6 (2016), 49.

13 „Science Fiction in China: 2016 in Review” [Science fiction w Chinach: przegląd roku 2016], Amazing Stories, dostęp 12.06.2017, http://amazingstoriesmag.com/2017/02/science-fiction-in-china-2016-in-review/.
} 
trwa od lat 90. aż do dziś, a samo Nowe Pokolenie „wyrywało je [science fiction] ze skostniałych schematów"14. Nowe Pokolenie nie tylko rozwija science fiction pod względem różnorodności stylu czy innowacyjności, ale dekonstruuje mit antropocentryzmu, kwestionuje jego wszechmoc, porusza tematy rozwoju ludzkiej cywilizacji i potencjalnych niebezpieczeństw czy też problemów etycznych, jakie może ona napotkać ${ }^{15}$. W utworach powstałych po latach 90. przyszłość jest pełna wielkich kryzysów, ale i wielkiego potencjału ${ }^{16}$. Pisarka Xia Jia (夏笳, Xià Jiā) w swoim eseju zwraca uwagę, że „okres wielkich transformacji odsunął [science fiction] od marzeń o przyszłej modernizacji, by zająć się o wiele bardziej skomplikowaną rzeczywistością społeczeństwa" ${ }^{17}$. Zgodnie ze słowami Jeana Baudrillarda science fiction stało się dla chińskich twórców idealnym narzędziem do komentowania nieustannie zmieniającej się teraźniejszości, a potwierdzają to słowa Chen Qiufana (陈楸帆, Chén Qiūfān): „W obliczu absurdalnej rzeczywistości współczesnych Chin pisarz nie może w pełni zgłębić czy też wyrazić możliwości ekstremalnego piękna i ekstremalnej brzydoty bez uciekania się do science fiction" 18 .

Jedną z autorek zaliczanych do Nowego Pokolenia jest Hao Jingfang, która w swoim opowiadaniu „Składający się Pekin” tworzy rozbudowaną metaforę rozwarstwionego społeczeństwa, uwięzionego w stanie nieustannej zmiany i mieście molochu. Utwór zdobył w 2016 r. prestiżową nagrodę Hugo w kategorii najlepsze opowiadanie, co zwróciło uwagę całego świata literatury science fiction - po precedensie ustanowionym rok wcześniej przez Liu Cixina (刘慈欣, Liú Cíxīn) i jego powieść pt. Problem trzech ciat (三体, Sāntǐ) Hao Jingfang stała się drugim pisarzem spoza kręgu europejsko-amerykańskiego, który został wyróżniony w tym corocznym konkursie.

${ }^{14}$ YÁNG Yànjiā, „Rénlèi zhōngxīn shénhuà de jiěgòu-lùn zhōngguó xīnshēngdài kēhuàn xiăoshuō tèzhēng zhī ȳ̄” [Dekonstrukcja mitu antropocentryzmu - o jednej z cech Nowego Pokolenia chińskiego science fiction], Guăngdōng Jishù Shîfàn Xuéyuàn Xuébào [Czasopismo Guandong Normal University] 4 (2011): 90.

${ }^{15}$ Xú Gāng, „Xīn shìjì zhōngguó. Kēhuàn wénxué de liúbiàn” [Chiny w nowym wieku. Ewolucja literatury science fiction], Yuèhăifēng [Wieści z Guandong-Hainanu] 6 (2011): 48.

${ }^{16}$ LiU Cixin, „The Worst of All Possible Universes and the Best of All Possible Earths: Three-Body and Chinese Science Fiction" [Najgorszy z możliwych wszechświatów i najlepsza z możliwych Ziemi: Trzy Ciała oraz chińskie science fiction], w: Ken Liu, Invisible Planets: An Anthology of Contemporary Chinese Science Fiction [Niewidzialne Planety. Antologia współczesnego chińskiego science fiction] (London: Head Zeus, 2016), 366.

${ }^{17}$ XIA Jia, ,What Makes Chinese Science Fiction Chinese?” [Co czyni chińskie science fiction chińskim?]", w: KeN, Invisible Planets: An Anthology, 381.

${ }^{18}$ CHEN Qiufan, „The Torn Generation: Chinese Science Fiction in a Culture in Transition” [Rozdarte pokolenie: chińskie science fiction w kulturze w fazie przejściowej], w: Ken, Invisible Planets: An Anthology, 372. 
Przez całą fabułę, wraz z głównym bohaterem Lao Dao (老刀, Lăo Dāo), czytelnik może podziwiać wizję Pekinu z przyszłości, podzielonego na trzy obszary, które istnieją w jednej przestrzeni, składając się i rozkładając wedle odgórnie ustalonych zasad. Opowiadanie powstało jako reakcja na problemy towarzyszące życiu we współczesnych Chinach, takie jak rozwarstwienie społeczne, niemożność odnalezienia się w gwałtownie zmieniającym się świecie czy też wpływ rozwoju technologicznego na społeczeństwo.

Hao Jingfang urodziła się w 1984 r. w Tianjinie ${ }^{19}$. W 2002 r. zdobyła pierwsze miejsce w konkursie Nowych Koncepcji (第四届新概念作文大赛, Dìsìjiè xīn gàiniàn zuòwén dàsài) na szczeblu gimnazjalnym, pisząc o nauce, filozofii i literaturze zamiast o problemach i bólach dorastania ${ }^{20}$. W liceum zafascynowała się science fiction, przez co podjęła studia na wydziale fizyki Uniwersytetu Qinghua, doktorat jednak uzyskała na wydziale ekonomii i zarządzania. Po ukończeniu studiów rozpoczęła pracę w fundacji zajmującej się badaniami ekonomicznymi i niesieniem pomocy najbiedniejszej warstwie społecznej w Chinach ${ }^{21}$.

Pisarka do tej pory wydała między innymi powieść pt. Wędrujące Niebiosa (流浪苍穹, Liúlàng cāngqióng) oraz zbiory opowiadań Gwiezdny podróżnik (星旅人, Xīnglürén), Idąc daleko (去远方, Qù yuănfāng) i Samotna głębina (孤独深处, Gūdú shēnchù), nie ogranicza się jednak tylko do science fiction - jej najnowsza powieść, Urodzona w roku 1984 (生于一九 八四, Shēngyú ȳ̄jiǔbāsì) zaliczana jest do literatury realistycznej ${ }^{22}$. Opowiadanie „Lato w domu babci” (祖母家的夏天, Zǔmǔjiā de xiàtiān) zostało nagrodzone w corocznym konkursie Droga Mleczna (银河奖, Yínhé jiăng).

Styl pisarski Hao Jingfang został scharakteryzowany przez Liu Cixina w następujący sposób: „zupełnie jakby powróciło zachodzące słońce, które zniknęło na długi czas, i dodało science fiction poetyckiego smaku" ${ }^{23}$. W jej utworach niewiele jest elementów hard science fiction, za to odnaleźć można wiele motywów dotyczących problemów społecznych i ekonomicznych. Twórczość autorki umiejscawia się $\mathrm{w}$ przestrzeni między literaturą science fiction a tą należącą do głównego nurtu, sama Hao nazywa ją „literaturą bez gatunku”24.

\footnotetext{
${ }^{19}$ RÈN, ,Cóng kēhuàn xiànshí”, 46.

${ }^{20}$ HǍI Xīn. „Hăoǰ̌ngfāng de shìjiè-xiànshí zhōngguó de kēhuàn 'liúpài’” [Świat Hao Jingfang — „nurt” współczesnego chińskiego science fiction], Qílǔ Zhōukān [Tygodnik Qilu] 29 (2016): 72 .

21 Ibid.

${ }^{22}$ KEN, Invisible Planets: An Anthology of Contemporary Chinese Science Fictions, 197.

${ }^{23}$ RÈn, „Cóng kēhuàn xiànshí”, 47.

${ }^{24}$ Ibid.
} 
Hao Jingfang w przedmowie do Idac daleko dzieli powieści na te opisujące „rzeczywistą” [现实, xiànshí] i „fikcyjną” [虚拟, xūnǐ] przestrzeń — pierwsza ma dotyczyć „czystej literatury” [纯文学, chún wénxué] czy też „literatury głównego nurtu” [主流文学, zhǔliú wénxué], natomiast druga literatury fantasy [奇幻文学, qíhuàn wénxué] i science fiction [科幻文学, kēhuàn wénxué]. To właśnie na skraju obu tych rodzajów ma mieścić się twórczość autorki, która pozostaje bliska „rzeczywistości”, jednocześnie opisując „fikcję”. Ta wypowiedź autorki posłużyła Ren Dongmei (任东梅, Rèn Dōngméi) za punkt wyjścia do analizy "Składającego się Pekinu” z punktu widzenia „realizmu science fiction” 25 .

Realizm science fiction podkreśla, obok „naukowości” i „fantastyczności”, przede wszystkim realistyczne elementy w utworach science fiction. W swoim opracowaniu Ren Dongmei przytacza słowa jednego z najwybitniejszych współczesnych pisarzy science fiction, Stanleya Chana (陈楸帆, Chén Qiūfān): ,aktualnie science fiction jest najbardziej realistyczne [realistyczną literaturą]. Science fiction, swobodnie wykorzystując realizm, dostarcza wyobraźni medium, opisując rzeczywistość nieopisaną przez literaturę głównego nurtu" ${ }^{26}$. Science fiction ma zapełniać luki pozostawione przez literaturę głównego nurtu, poruszając tematy tabu i pozostając blisko rzeczywistości. Podążając tym tokiem rozumowania, Ren Dongmei stwierdza, że dzięki użyciu „fantastyki” Hao Jingfang może lepiej wyrazić rzeczywistość ${ }^{27}$.

Jednym z najważniejszych wyznaczników realizmu science fiction jest rekonstrukcja i krytyka rzeczywistości. Pod tym względem „Składający się Pekin" zdecydowanie można zaliczyć do tego nurtu literackiego - wykreowany obraz Pekinu z przyszłości jest refleksją na temat problemów współczesności, takich jak podziały społeczne czy redukcja miejsc pracy ze względu na postęp technologiczny. Hao Jingfang wykorzystuje elementy charakterystyczne dla literatury science fiction, takie jak dystopia czy wysoko rozwinięta technologia, są one jednak użyte jako maska w celu przedstawienia wybranych współczesnych problemów. Nie ogranicza się jednak tylko do tych technik i motywów - Hua Yan wskazuje na występowanie w „Składającym się Pekinie” licznych elementów typowych dla literatury gotyckiej, takich jak gotycka sceneria, gotycki wędrowiec, gotycka groza i motyw transgresji ${ }^{28}$.

\footnotetext{
${ }^{25}$ Ibid.

${ }^{26}$ Ibid.

${ }^{27}$ Ibid.

${ }^{28}$ HuA Yan, „Gothic Elements in Folding Beijing” [Elementy gotyckie w „Składającym się Pekinie"], Academics 11 (2016): 277.
} 
Akcja opowiadania podąża za podróżą Lao Dao, pracownika zakładu oczyszczania miasta. Bohater decyduje się podjąć niebezpieczne zadanie dostarczenia listu miłosnego, by zdobyć potrzebne pieniądze, opłacić czesne i zagwarantować swojej adoptowanej córce, Tangtang (糖糖, Tángtáng), miejsce w przedszkolu prowadzącym zajęcia muzyczne. Rola kuriera wydawałaby się łatwa, Pekin przyszłości, w którym rozgrywają się wszystkie wydarzenia, znacznie jednak utrudnia to zadanie. Podczas modernizacji kilkadziesiąt lat temu miasto zostało podzielone na trzy przestrzenie, które funkcjonują w tym samym miejscu, dzieli je jednak czas. Pierwsza Przestrzeń, zamieszkiwana przez najlepiej prosperujących pięć milionów ludzi, funkcjonuje przez pełne dwadzieścia cztery godziny — od szóstej rano do szóstej rano następnego poranka. Gdy ustalony czas mija, Pierwsza Przestrzeń składa się, ustępując miejsca Drugiej Przestrzeni, będącej domem dla dwudziestu pięciu milionów członków klasy średniej. Ich czas trwa od szóstej rano do godziny dziesiątej wieczorem, dając w sumie szesnaście godzin. Ostatnia, Trzecia Przestrzeń liczy pięćdziesiąt milionów mieszkańców najniższej warstwy społecznej, którzy wykorzystują pozostałe osiem godzin, do szóstej rano, aż do ponownego rozłożenia się Pierwszej Przestrzeni. Stały cykl składania się i rozkładania poszczególnych przestrzeni wyznacza rytm życia dla wszystkich mieszkańców miasta, stanowi też trudną do przebycia barierę między wszystkimi trzema sferami.

By poznać sposób dostania się do Pierwszej Przestrzeni, Lao Dao najpierw udaje się do Peng Li (彭蟲, Péng Lí), przemytnika, który udziela mu potrzebnych wskazówek. Mając już potrzebną wiedzę, bohater udaje się na spotkanie ze swoim zleceniodawcą - mieszkającym w Drugiej Przestrzeni studentem, Qin Tianem (秦天, Qín Tiān). Qin Tian odbywał staż w Pierwszej Przestrzeni, gdzie zakochał się w Yi Yan (依言, Yī Yán). Pragnąc upewnić ją o stałości swoich uczuć, postanowił zlecić dostarczenie listu miłosnego mającego również zapewnić ukochaną o jego staraniach przeniesienia się na stałe do Pierwszej Przestrzeni.

Podczas swojej wędrówki Lao Dao przemierza wszystkie trzy przestrzenie, poznając przedstawicieli różnych warstw społecznych — począwszy od najbiedniejszych, mieszkających w Trzeciej Przestrzeni, poprzez Qin Tiana i jego współlokatorów zamieszkujących Drugą Przestrzeń aż po zamieszkującą Pierwszą Przestrzeń Yi Yan. Po udanym dostarczeniu listu zostaje aresztowany — z opresji ratuje go jednak Ge Daping (葛大平, Gé Dàpíng), człowiek, który dzięki karierze wojskowej awansował z Trzeciej Przestrzeni aż do Pierwszej. To dzięki jego pomocy Lao Dao nie tylko unika więzienia, 
ale ma okazję być świadkiem wykwintnego bankietu. Biorą w nim udział najbardziej wpływowi mieszkańcy Pekinu, czyli ci mający możliwość regulowania całego systemu zarządzającego miastem. Ostatnim niebezpieczeństwem, któremu czoło musi stawić Lao Dao, jest utknięcie w zmieniającym się mieście, zastygającym i cofającym się podczas Przemiany właśnie przez niezbędne dostosowanie godziny przejścia z Pierwszej do Drugiej Przestrzeni.

$\mathrm{Z}$ chwilą, gdy Pekin zatacza pełne koło, powracając do Trzeciej Przestrzeni, kończy się także wędrówka Lao Dao. Bohaterowi udaje się powrócić zwycięsko do domu - zdobył niezbędne pieniądze, decyduje się nawet na podzielenie się częścią z potrzebującą pomocy parą młodych kobiet, które zalegały z czynszem. Lao Dao jest w stanie zapewnić swojej córce miejsce w przedszkolu, jego życie jednak nie zmienia się — opowiadanie kończy się, gdy bohater spogląda na zegarek i stwierdza, że nadszedł czas pracy.

W „Składającym się Pekinie” narrator nie ujawnia się, przez całe opowiadanie pozostaje ukryty i zewnętrzny w stosunku do całej akcji i w niej nie partycypuje. Jedynym śladem jego obecności pozostaje sam akt „mówienia"- przedstawiania kolejnych wydarzeń i opisywania świata przedstawionego. Sytuacja narracyjna mieści się pomiędzy tą auktorialną ${ }^{29}$ [authorial narrative] i personalną ${ }^{30}$ [figural narrative], może być zaklasyfikowana jako narracja lustrzana ${ }^{31}$ [reflector-mode narration]. Fokalizator zmienia się na przestrzeni tekstu między zewnętrznym, na przykład gdy narrator przedstawia informacje dotyczące rzeczywistości, w jakiej rozgrywa się akcja, a wewnętrznym, kiedy narrator przedstawia punkt widzenia jednego z bohaterów (najczęściej Lao Dao, ale pojawiają się też nieliczne przypadki innych bohaterów-fokalizatorów).

Ze względu na nieujawnianie się narratora narratowany także pozostaje ukryty. Można go jednak częściowo określić dzięki sposobowi prowadzenia narracji, na przykład ekspozycji dotyczącej świata przedstawionego, mającej miejsce na początku drugiej części, co wskazuje na nieznajomość u narrato-

\footnotetext{
${ }^{29}$ Narracja auktorialna — narracja prowadzona z punktu widzenia kogoś, kto nie jest i nie będzie bohaterem danego tekstu narracyjnego, często jest wszechobecny i wszechwiedzący i zwraca się bezpośrednio do narratowanego. Mieke BAL, Narratologia. Wprowadzenie do teorii narracji, przekład zespołowy pod red. Ewy Kraskowskiej i Ewy Rajewskiej (Kraków: Wydawnictwo Uniwersytetu Jagiellońskiego, 2012) oraz Manfred JAHN, „Narratology: A guide to the Theory of Narrative" [Narratologia: Przewodnik teorii narracji], dostęp: 12.06.2017, http://www.unikoeln.de/ ame02/pppn.htm.

${ }^{30}$ Narracja personalna - narracja prowadzona z punktu „trzecioosobego lustra”, czasem nazywana „brakiem narratora” (ibid.).

${ }^{31}$ Narracja lustrzana - narracja prowadzona albo z punktu widzenia trzeciej osoby, albo z punktu widzenia bohatera (fokalizatora wewnętrznego) (ibid.).
} 
wanego realiów, w jakich rozgrywa się akcja utworu. Zabieg defamiliaryzacji kognitywnej ${ }^{32}$ został zastosowany oszczędnie, a nieznany Pekin przyszłości zostaje szybko zarysowany i przedstawiony narratowanemu i czytelnikowi, których wiedza na temat świata przedstawionego w opowiadaniu jest taka sama.

Narrator dokumentuje podróż Lao Dao i przybliża narratowanemu realia, w których rozgrywa się akcja, jednak sam pozostaje do niego zdystansowany. Nie ocenia i nie komentuje ani świata, ani wydarzeń, ani bohaterów, relacjonując jedynie przebieg zdarzeń i czasem dostarczając dodatkowych informacji. Dzięki zastosowaniu takiej formy narracji to czytelnik musi dokonać refleksji i oceny przedstawionej w „Składającym się Pekinie” wizji rzeczywistości.

Główny bohater „Składającego się Pekinu”, Lao Dao, zostaje nakreślony przez narratora. Nie przedstawia on jednak postaci wprost, charakteryzuje ją, nie mówiąc o konkretnych cechach, ale przytaczając fakty z życia czy też opisując reakcje Lao Dao na zaistniałe sytuacje. Przez zastosowanie kwalifikacji pośredniej to do czytelnika należy wyciągnięcie wniosków i ocena postaci. Sylwetka bohatera zostaje zarysowana już na samym początku opowiadania. Przez opis jedynego odświętnego kompletu ubrań, który i tak jest znoszony, narrator zwraca uwagę na codzienność Lao Dao, czterdziestosiedmioletniego kawalera, który już od dawna nie musiał dbać o swój wygląd, poza nielicznymi okazjami, takimi jak ślub czyjegoś dziecka. Lao Dao należy do nizin społecznych - mieszka w Trzeciej Przestrzeni i pracuje w przetwórni odpadów, bez większych szans na poprawę swojego życia czy awans społeczny. Jego ojciec pracował przy modernizacji Pekinu i przy powstawaniu trzech Przestrzeni, a prace zostały ukończone dwa lata przed urodzeniem się głównego bohatera. Historia jego przeciętnego, pozbawionego zwrotów akcji życia zostaje krótko streszczona przez narratora:

Lao Dao urodził się dwa lata po ukończeniu budowy składającego się miasta, nigdy go nie opuścił i nigdy o tym nie myślał. Ukończył szkołę podstawową i średnią. Trzy razy podchodził do egzaminów wstępnych na uniwersytet, ale nie zdał i ostatecznie został śmieciarzem. Codziennie pracował przez pięć godzin, od jedenastej wieczorem do czwartej nad ranem, wraz z niezliczonymi innymi współpracownikami szybko i mechanicznie sortował ręcznie śmieci, spośród skrawków życia przekazanych z Pierwszej i Drugiej Przestrzeni wybierając to, co nadawało się do przetworzenia i wrzucając je do pieca utylizującego. Codziennie stawał przed rzeką śmieci płynących taśmą, wygrzebywał resztki jedzenia z plastikowych opakowań, wybierał strzaskane fragmenty szkła, odrywał nieskażoną folię z tyłu

\footnotetext{
${ }^{32}$ Nodelman, „The Cognitive Estragement”, 24-27.
} 
zabrudzonych krwią podpasek i wrzucał do oznaczonych zieloną taśmą pojemników na odpady odnawialne. To była ich dola, zarabiać na życie prędkością, wymieniać przerobione śmieci na nikłe niczym skrzydła cykad wypłaty ${ }^{33}$.

Lao Dao, pomimo sytuacji, w jakiej się znajduje, nie buntuje się i nie walczy z nią — przyjmuje swój los z pokorą i spokojem: „był śmieciarzem, od dwudziestu ośmiu lat zajmował się przetwarzaniem śmieci i będzie to nadal robił w dającej się przewidzieć przyszłości. Nadal nie odnalazł ani sensu swojego życia, ani ostatecznego sceptycyzmu. Zamiast tego trwał na miejscu w skromnym życiu." ${ }^{34}$.

Lao Dao jawi się jako bohater przeciętny, nie wyróżnia się żadnymi wybitnymi cechami, wydaje się być typowym przedstawicielem mieszkańca Trzeciej Przestrzeni Pekinu, czyli kogoś należącego do nizin społecznych. Podczas akcji opowiadania nie podlega przemianom, przez co może zostać nazwany „bohaterem niedynamicznym” [static character]. Jego sytuacja życiowa nie zmienia się, zaczyna jako śmieciarz i nim pozostaje, jedyną zmianą jest umożliwienie Tangtang uczęszczania do muzycznego przedszkola i szansa na zapewnienie jej lepszej przyszłości. Reakcje Lao Dao na kolejne wydarzenia są przedstawiane jedynie na tyle dokładnie, aby był realistyczny pod kątem psychologicznym — narrator wskazuje na to, że bohater odczuwa strach czy też zachwyt, ale nie przytacza monologów wewnętrznych bohatera.

Przez brak szczególnych cech charakterystycznych Lao Dao może zostać zaklasyfikowany jako everyman - część czytelników może się z nim utożsamiać, chociażby przez wzgląd na motywację, jaka przyświeca głównemu bohaterowi. Porywa się na niebezpieczne zadanie, by zapewnić swojej adoptowanej córce Tangtang lepszą edukację i w perspektywie lepszą przyszłość, co nie jest obce rodzicom, którzy poświęcają wszystko dla swoich dzieci, czy to pracując jak najwięcej, by zapewnić im byt, czy też rezygnując z pracy, by pomóc w przygotowaniu do egzaminów wstępnych na uczelnię, które zadecydują o ich dalszym losie. Jest to problem bardzo aktualny we współczesnych Chinach, na co zwraca uwagę w swojej recenzji Chen Rong ${ }^{35}$.

Taki sposób konstrukcji głównego bohatera pełni jeszcze jedną funkcję - pozwala czytelnikowi skupić się na innych aspektach opowiadania.

\footnotetext{
${ }^{33}$ HǍO, „Běijīnng Zhédié”. Wszystkie fragmenty opowiadania zostały na potrzeby artykułu przetłumaczone z języka chińskiego możliwie najwierniej.

${ }^{34}$ Ibid.

${ }^{35}$ CHÉN Róng, „Běijīng zhédié: Huídào yuándiăn de lŭxíng” [„Składający się Pekin”: podróż powrotna do punktu wyjścia], Xīndōngfāng Yīngyǔ [Angielski Nowoorientalny] 11 (2016): 40.
} 
W tym wypadku postać głównego bohatera usuwa się w cień, pozwalając, by pierwszoplanową rolę odgrywał opis dystopijnej przyszłości przedstawionej w „Składającym się Pekinie”. Lao Dao w trakcie trwania akcji opowiadania nie przeżywa gwałtownych wzlotów i upadków ani nie walczy z systemem, stara się jedynie poradzić sobie jak najlepiej w swoim życiu. Dla niektórych recenzentów jest to powód do krytyki, dzięki temu jednak uwaga czytelnika może skupić się na wizji społeczeństwa zamieszkującego Pekin ${ }^{36}$. W swojej analizie Ma Yuhua (马予华, Mă Yǔhuá) uznaje taką konstrukcję głównego bohatera za niewątpliwą zaletę opowiadania - Lao Dao staje się dzięki temu swoistym ,wehikułem dla fabuły"37.

Hua Yan, analizując „Składający się Pekin” pod kątem nawiązań do literatury gotyckiej, zwraca uwagę na podobieństwo Lao Dao do gotyckiego wędrowca [gothic wanderer]. Badaczka wskazuje, że Lao Dao wyrusza w podróż, podczas której przekracza granice, łącząc różne światy - czy to przenosząc list Qin Tiana z Drugiej Przestrzeni do rąk mieszkającej w Pierwszej Przestrzeni Yi Yan, czy też dostarczając przesyłkę dla chorych rodziców Lao Ge z Pierwszej do Trzeciej przestrzeni ${ }^{38}$. W kontekście dokonywanych transgresji imię głównego bohatera staje się znaczące - Lao

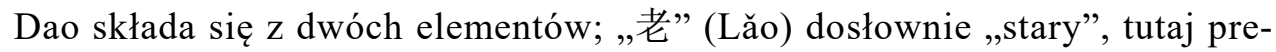
fiks dodawany do nazwisk, wskazujący na zażyłość oraz „刀” (Dāo), chińskie nazwisko, które oznacza dosłownie „nóż” lub „miecz”. Lao Dao podczas swoich podróży przekracza kolejne bariery między trzema Przestrzeniami, przeszywając je właśnie na podobieństwo noża.

Pozostali bohaterowie „Składającego się Pekinu” pojawiają się tylko epizodycznie i tak samo jak Lao Dao są postaciami statycznymi — ani ich charakter, ani ich sytuacja nie zmienia się przez całą fabułę. Każdy z nazwanych bohaterów pełni określoną funkcję: Qin Tian wysyła głównego bohatera na misję, Yi Yan jest celem jego wędrówki, Peng Li dostarcza Lao Dao niezbędnej wiedzy, a Lao Ge wybawia go z opresji. Poza tymi określonymi funkcjami pozostałe postaci odgrywają jeszcze jedną, bardzo ważną rolę — każda z nich reprezentuje jedną z wielu grup społecznych zamieszkujących Pekin - w tym sensie mogą być nazwani bohaterami archetypicznymi.

Tym, który umożliwił Lao Dao bezpieczne przemieszczanie się między poszczególnymi Przestrzeniami Pekinu, był Peng Li, mieszkaniec Trzeciej

\footnotetext{
${ }^{36}$ MǍ Yǔhuá, „Běijīnng zhédié: zhōngguóhuà kēhuàn de xùshì yǔ xiànshí” [,,Składający się Pekin": narracja i rzeczywistość science fiction w chińskim stylu], Chūbăn Guăngjiăo [Szeroki Przegląd Publicystyczny] 2016, 276: 93.

${ }^{37}$ Ibid.

${ }^{38}$ HuA, ,Gothic Elements in Folding Beijing”, 280.
} 
Przestrzeni. Za młodu zajmował się przemytem między Trzecią a Pierwszą Przestrzenią. Miał ponad sześćdziesiąt lat i nie dbał o swój wygląd, chodził niespiesznie, żując wykałaczkę i co jakiś czas bekając. Jego obwisłe policzki sprawiały, że wyglądał, jakby ciągle był w złym humorze. W przeciwieństwie do Lao Dao, który porwał się na niebezpieczną wyprawę, Peng Li jest „wystarczająco stary, by być leniwym i zmęczonym wszystkim" 39 i nie ryzykował już zajmowania się szmuglerstwem, widząc jednak zdecydowanie głównego bohatera, podzielił się z nim swoją wiedzą.

Przedstawicielami typowych mieszkańców Drugiej Przestrzeni są Qin Tian i jego współlokatorzy. Wszyscy są studentami, którzy liczą na to, że dzięki ciężkiej pracy będą mogli polepszyć swoje życie, awansować społecznie i zamieszkać w Pierwszej Przestrzeni. Historia życia Qin Tiana, opowiadana Lao Dao, zostaje streszczona przez narratora. Podczas praktyk odbywanych w Pierwszej Przestrzeni młody student poznał Yi Yan, w której się zakochał. Aby móc być ze swoją ukochaną, planował aplikować do programu, który pozwoliłby mu przenieść się i pracować w Pierwszej Przestrzeni. Qin Tian obawiał się reakcji rodziców Yi Yan; zakochany student chciał więc nieoficjalnymi kanałami upewnić swoją wybrankę o swoich uczuciach i tęsknocie, przesyłając własnoręcznie wykonany naszyjnik.

Ukochana Qin Tiana, Yi Yan, jest typową mieszkanką Pierwszej Przestrzeni Pekinu - tam się urodziła i wychowała. Gdy Lao Dao ją znajduje, okazuje się, że Yi Yan okłamała Qin Tiana — gdy się poznali, była już zaręczona, a gdy dociera do niej list, jest już zamężna. Nie zamierza rozstać się ze swoim mężem, nie chce też jednak zranić uczuć Qin Tiana, dlatego nalega, by Lao Dao nie wyjawił mu prawdy, tylko przekazał wiadomość: „powiedz mu, że nie mogę z nim teraz być, ale naprawdę go lubię" ${ }^{, 40}$.

Opis wyglądu Yi Yan zdecydowanie różni się od wcześniejszych charakterystyk mieszkańców Trzeciej Przestrzeni - Yi Yan była elegancka, ale „nie aż tak piękna jak opisał ją Qin Tian”41. W oczach obserwującego ją Lao Dao Yi Yan była dobrze ubraną, smukłą kobietą o całkiem niezłej figurze i drobnej budowie. Wygląd jej męża, Wu Wena (吴闻, Wú Wén), także wyraźnie różnił się od wyglądu mieszkańców Trzeciej Przestrzeni. Nie miał żadnych cech szczególnych, nosił dopasowany szary garnitur, a jego włosy były schludnie zaczesane na bok.

\footnotetext{
${ }^{39}$ HǍO, „Běijīng Zhédié”.

${ }^{40}$ Ibid.

${ }^{41}$ Ibid.
} 
Tak samo jak w przypadku Qin Tiana, tak i w przypadku Yi Yan to narrator streszcza jej historię życia, którą opowiada ona Lao Dao. Pracowała ponad dwa lata jako asystentka w banku, a na szkolenie, podczas którego poznała Qin Tiana, została wysłana, by pomóc w organizacji. Ona sama, tak jak wiele żon żyjących w Pierwszej Przestrzeni, nie musiała pracować, podjęła jednak pracę na pół etatu, żeby się nie nudzić.

Podczas swojego pobytu w Pierwszej Przestrzeni Lao Dao wpada w kłopoty - zostaje zatrzymany na ulicy przez służby porządkowe, które nie odnalazły go w rejestrze. $Z$ opresji ratuje go Lao Ge, były mieszaniec Trzeciej Przestrzeni, który dzięki swoim umiejętnościom i ciężkiej pracy zamieszkał w Pierwszej Przestrzeni. Jest on przedstawicielem tych mieszkańców Pekinu, którym udało się awansować i polepszyć swoje życie. Rozmowa, podczas której Lao Dao poznaje historię Lao Ge, również zostaje streszczona przez narratora. Lao Ge, tak samo jak główny bohater, dorastał w Trzeciej Przestrzeni, a jego rodzice zajmowali się dostarczaniem przesyłek. Dostał się do szkoły wojskowej, a później pracował jako żołnierz. Dzięki sumienności i umiejętnościom awansował aż do rangi starszego pułkownika, ponieważ jednak nie pochodził z prominentnej rodziny, dalszy rozwój kariery wojskowej nie był możliwy. Zamiast tego przeniósł się do służby cywilnej, gdzie zajmował się pomocą w organizacji i koordynacji różnego rodzaju oficjalnych wydarzeń. Jako wysoko wykwalifikowany pracownik miał zagwarantowane miejsce w Pierwszej Przestrzeni.

Ostatnią z grup społecznych, które zamieszkują Pekin, są wszyscy ci, którzy odgórnie zarządzają miastem. Są to ludzie, którzy mają największą władzę i wpływ na to, jak funkcjonuje metropolia. To oni doglądają mechanizmu Zmiany (转变, Zhuănbiàn) regulującego życie we wszystkich trzech Przestrzeniach. Przedstawicielem tej grupy jest siwowłosy mówca — bohater, który pozostaje nienazwany w całym opowiadaniu, co podkreśla dystans między nim a pochodzącym z nizin społecznych Lao Dao. Interakcje głównego bohatera $\mathrm{z}$ "siwowłosym mówcą" są znikome - Lao Dao jest jedynie świadkiem jego rozmowy z Wu Wenem. Ani Lao Dao, ani narratowany nie poznają bliżej „siwowłosego mówcy”, mimo że przez krótki fragment to właśnie on jest fokalizatorem - narrator z jego punktu widzenia przygląda się procesowi opóźniania Zmiany:

[Lao Dao] [s]pojrzał w kierunku stojącego na platformie mówcy, był to starszy i siwowłosy człowiek, który mimo tego wyglądał nadzwyczaj dziarsko. Siwowłosy mówca po bankiecie powrócił do swojego biura, zajął się kilkoma dokumentami i przeprowadził wideokonferencję z Europą. O północy poczuł znużenie, zdjął 
okulary i rozmasował obie strony nosa, szykując się do powrotu do domu. Często pracował do późna. [...] O piątej nad ranem sekretarka zadzwoniła $\mathrm{z}$ wiadomością, że materiały zostały już wydrukowane, ale jeszcze nie opuściły drukarni, i zapytała, czy powinni opóźnić Zmianę. Siwowłosy starszy człowiek bez cienia wątpliwości odpowiedział, co to za nonsens, oczywiście, że opóźnić. [...] Dziesięć po szóstej dystrybucja została zakończona. Siwowłosy starszy człowiek westchnął z ulgą i wydał rozkaz do rozpoczęcia Zmiany. [...] O szóstej dwadzieścia sekretarka zadzwoniła z pilną sprawą [...] Siwowłosy starszy człowiek był poirytowany, ale nie miał wyjścia, wydał rozkaz zatrzymania Zmiany i powrotu do stanu pierwotnego. [...] O szóstej czterdzieści pięć wykończony siwowłosy starszy człowiek w końcu położył się na małym łóżku w biurze. Rozkaz został wydany, tryby poruszające światem zaczęły się powoli obracaćc ${ }^{42}$.

Statyczni bohaterowie odgrywają więc swoje role, przedstawiając typowy styl życia różnych grup społecznych zamieszkujących Pekin, żaden z nich jednak nie przechodzi wewnętrznej przemiany - wszyscy pozostają w tych samych miejscach. Nawet rozmowy głównego bohatera z pozostałymi postaciami są streszczane przez narratora - same dialogi nie są istotne dla opowiadania, tylko ich treść, która służy do pokazania wykreowanego wizerunku świata przedstawionego. Podróż Lao Dao jest motywacją do ukazania różnych miejsc i bohaterów, a oni sami są jedynie pretekstem, by zarysować jedną z możliwych wizji Pekinu przyszłości. Wszyscy bohaterowie stają się tłem dla opisu przestrzeni, w której żyją i która definiuje ich świat.

Miejsca, w których rozgrywa się akcja opowiadania, są równie zróżnicowane między sobą, co bohaterowie, i tak samo jak oni są statyczne i wewnętrznie spójne. Każda $z$ trzech Przestrzeni ma swoje cechy charakterrystyczne, które odzwierciedlają styl życia i status ich mieszkańców. Są od siebie wyraźnie oddzielone - nie mogą istnieć równolegle w tym samym czasie, zajmując to samo miejsce w wyznaczonych odgórnie godzinach. Sprawia to, że punkty styczne między nimi są praktycznie nieistniejące, oddziela je od siebie proces Zmiany, podczas którego Przestrzenie składają się i rozkładają według ustalonego planu.

Przestrzeń w „Składającym się Pekinie” opisywana jest przez narratora i najczęściej fokalizowana przez Lao Dao, który podróżuje przez kolejne miejsca, by wykonać powierzone mu zadanie. Narrator przytacza jego reakcje zarówno na znajomą i bliską mu Trzecią Przestrzeń, jak i całkowicie nowe i zaskakujące dla bohatera widoki Pierwszej Przestrzeni. Różnice między trzema Przestrzeniami, na które podzielony jest Pekin, są wyraźnie zarysowane, a opisy ulic, mieszkań czy też jedzenia w każdej lokacji kontrastują ze sobą.

\footnotetext{
${ }^{42}$ Ibid.
} 
Pierwszym miejscem, które zostaje opisane, jest Trzecia Przestrzeń punkt początkowy, a zarazem też końcowy podróży Lao Dao. Zamieszkiwana przez pięćdziesiąt milionów mieszkańców zajmujących się głównie przetwórstwem śmieci jest zatłoczona i głośna:

Deptak był pełen ludzi, którzy dopiero co skończyli pracę. Tłumy mężczyzn i kobiet oblegały małe stragany z lokalnymi produktami, głośno się targując. Klienci otaczali plastikowe stoliki, pochylając głowy nad gorącym ostro-kwaśnym makaronem, pożerali go jak wygłodniałe tygrysy, a ich twarze nikły w białych oparach. Wszystko było przesiąknięte zapachem oleju. Na straganach piętrzyły się góry owoców głożyny i orzechów włoskich, a paski suszonego mięsa kołysały się nad głowami. To był najgwarniejszy czas w ciągu całego dnia, praktycznie cała praca dobiegła końca, po ciężko przepracowanych kilku godzinach wszyscy spieszyli tutaj, by najeść się do syta wśród gorączkowej wrzawy. [...] Lao Dao z trudem przeciskał się przez thum. Niosący tacę kelner, krzycząc: przepuśćcie, przepuśćcie, rozpychał blokujących drogę ludzi i tworzył przejście, a Lao Dao podążał tuż za nim ${ }^{43}$.

Różnice między ulicami i mieszkańcami Trzeciej a Drugiej Przestrzeni zostają zauważone i wymienione przez obserwującego przez okno toczące się codzienne życie Lao Dao:

Lao Dao spojrzał na ulicę przez okno. Nie mógł przywyknąć do światła słonecznego na zewnątrz. Słońce było białawe, a nie żółte. Ulica oświetlona promieniami słonecznymi zdawała się szersza, Lao Dao nie wiedział, czy mu się wydawało, ale chyba była dwa razy większa niż te z Trzeciej Przestrzeni. Budynki wcale nie były takie wysokie, o wiele niższe niż w Trzeciej Przestrzeni. Ludzi na zewnątrz było wielu, wszyscy pędzili w pośpiechu, przemykając ulicami, czasami ktoś chciał przebiec, przepychając się przez tłum, ludzie przed nim też przyspieszali podczas przechodzenia przez skrzyżowanie, wszyscy przypominali biegaczy. Większość ubrana była schludnie, mężczyźni w garnitury, kobiety w koszule i spódniczki, z apaszkami zwisającymi z szyi, z solidnymi torebkami w dłoniach, co nadawało im kompetentnego wyglądu. Ulice były pełne aut, co jakiś czas dostrzegał kierowców wystawiających głowę przez okna, spoglądających nerwowo w przód. Lao Dao bardzo rzadko widywał takie ilości aut, przywykł do magnetycznej kolejki i wypełnionych pasażerami wagonów, które przemykały obok jak podmuchy wiatru" 44 .

Wizyta w Pierwszej Przestrzeni wywarła na głównym bohaterze jeszcze większe wrażenie:

Lao Dao nigdy nie widział czegoś takiego. Słońce powoli wschodziło, niebo było koloru głębokiego czystego błękitu z pomarańczowawym skrajem tuż nad hory-

\footnotetext{
43 Ibid.

${ }^{44}$ Ibid.
} 
zontem i cienkimi nitkami ciągnących się chmurek. Słońce było blokowane przez dachy sąsiednich budynków, przez co wydawały się nadzwyczaj ciemne, a ich tło było oślepiająco jasne. Gdy słońce wschodziło, błękit nieba rozjaśniał się, ale stawał się jeszcze bardziej czysty i spokojny. Lao Dao podniósł się i pobiegł w kierunku słońca. Chciał pochwycić ten niknący złoty kolor. Na tle błękitnego nieba można było dostrzec odcinające się zarysy drzew. Jego serce podskakiwało jak szalone. Nigdy by się nie spodziewał, że wschód słońca może tak bardzo poruszać. [...] Wrócił do parku, który opuścił tego ranka i ze zdumieniem odkrył, że jest on wypełniony przychodzącymi i wychodzącymi ludźmi. Dwa rzędy miłorzębów na zewnątrz parku wyglądały dostojnie i bujnie. Małe czarne auta wjeżdżały przez bramę. Większość ludzi w parku nosiła dopasowane garnitury wykonane z połyskliwego materiału, inni mieli na sobie oficjalne czarne stroje w stylu chińskim, wszyscy roztaczali wokół siebie wyniosłą aurę. Było też kilku obcokrajowców. Niektórzy dyskutowali ze swoimi sąsiadami, inni witali się z oddali, śmiejąc się i machając do siebie, gdy się do siebie zbliżali ${ }^{45}$.

W każdej z trzech Przestrzeni Lao Dao odwiedza lokum jednego z jej mieszkańców, które przedstawia typowe warunki, w jakich żyją przedstawiciele różnych warstw społecznych Pekinu. Pierwszym z nich jest mieszkanie Peng Li, standardowe dla mieszkańca Trzeciej Przestrzeni:

Peng Li zabrał Lao Dao na górę, weszli do mieszkania. Jego kawalerka nie różniła się niczym od zwykłego mieszkania komunalnego, pokój o powierzchni sześciu metrów kwadratowych, łazienka, aneks kuchenny, stół, krzesło, kapsułowe łóżko, a pod nim szafka z szufladami, w których można było przechowywać ubrania i inne przedmioty. Ściany pokryte były zaciekami i śladami butów, nie były niczym ozdobione, tylko na kilku krzywo przyklejonych haczykach wisiały kurtka i spodnie ${ }^{46}$.

Podczas pobytu w Drugiej Przestrzeni Lao Dao zwiedzał mieszkanie należące do Qin Tiana. Składało się ono z czterech jednoosobowych pokoi, wspólnej kuchni i dwóch łazienek, które swoją wielkością wzbudziły zdziwienie głównego bohatera. Natomiast w Pierwszej Przestrzeni Lao Dao został zabrany do pokoju hotelowego przez Lao Ge:

Starszy mężczyzna zabrał go do pokoju. [Lao Dao] odkrył, że to pokój hotelowy, ogromny, jeszcze większy niż pokój gościnny Qin Tiana, wydawał się dwa razy większy niż jego wynajmowane mieszkanie. Pokój miał przytłumiony złotobrązowy kolor, a na środku stało szerokie dwuosobowe łoże. Na ścianie za wezgłowiem znajdowały się abstrakcyjny obraz o zmieniających się kolorach, przeszklone drzwi z białymi półprzezroczystymi zasłonami, a przed nimi mały stolik i dwie sofy ${ }^{47}$.

\footnotetext{
${ }^{45}$ Ibid.

${ }^{46}$ Ibid.

${ }^{47}$ Ibid.
} 
Różnice między trzema Przestrzeniami można zauważyć także, porównując sceny jedzenia — każda z nich przedstawia różne realia życiowe mieszkańców Pekinu. Sam główny bohater, mieszkający w Trzeciej Przestrzeni, oszczędza także na jedzeniu, by być w stanie zapłacić czesne za przedszkole, do którego chce posłać swoją adoptowaną córkę, Tangtang. W przeciwieństwie do tanich dań sprzedawanych w Trzeciej Przestrzeni mieszkańcy Drugiej Przestrzeni mogą $\mathrm{w}$ dowolnej chwili pobrać, co chcą, $\mathrm{z}$ automatów i dystrybutorów, a elita z Pierwszej Przestrzeni może raczyć się najbardziej wykwintnymi potrawami, kosztującymi więcej, niż Lao Dao jest w stanie zarobić w ciągu roku. Gdy Lao Dao czeka na powrót Peng Li, jest świadkiem rozmowy jedzących nastolatków mieszkających w Trzeciej Przestrzeni:

Z obu stron otaczała go wygłodniała grupa nastolatków pożerająca swój posiłek. [...] Każdy $\mathrm{z}$ nich miał przed sobą miskę jednego $\mathrm{z}$ dwóch typów smażonego makaronu, kilka osób dzieliło się dwoma porcjami, oba dania były porozrzucane dookoła, pałeczki grzebały w nich bez ustanku w poszukiwaniu kawałków mięsa pośród zbitek ostrych papryczek. [...]

- Ej, wiecie ile tam kosztuje podwójnie gotowana wieprzowina? — zapytał nastolatek o nazwisku Li.

— Cholera, w żarciu jest piasek — powiedział nagle, zakrywając usta, inny, grubawy nastolatek o nazwisku Ding [...]

- Ci tam za jedną porcję podwójnie gotowanej wieprzowiny biorą trzysta czterdzieści - powiedział Li. - Trzysta czterdzieści! A za gotowaną wołowinę czterysta dwadzieścia.

— Jak ten szajs może być tak drogi? — wymamrotał Ding, trzymając się za policzek $^{48}$.

Podczas pobytu w mieszkaniu Qin Tiana Lao Dao obserwował, jak jeden z lokatorów korzysta $\mathrm{z}$ automatu do wydawania jedzenia, który w każdej chwili może zaspokoić głód mieszkańca Drugiej Przestrzeni. Lao Dao miał też okazję dwa razy być świadkiem typowych posiłków mieszkańców Pierwszej Przestrzeni. Pierwszy raz podczas rozmowy z Yi Yan w typowej restauracji. Roboty pełniły funkcje kelnerów, a posiłki były wykwintne i elegancko podane. Lao Dao wziął też udział $\mathrm{w}$ bankiecie, na którym bawiła się śmietanka towarzyska Pierwszej Przestrzeni:

Zszedłszy na dół, Lao Dao odkrył, że był tam tłum ludzi. Wyglądało na to, że właśnie się rozpierzchli, rozmawiając $w$ małych grupkach w wielkiej sali. $Z$ jej jednej strony było miejsce spotkań, drzwi do niego nadal były otwarte, wydawały się bardzo grube, obite czerwono-brązową skórą. $Z$ drugiej strony rozstawione poje-

\footnotetext{
${ }^{48}$ Ibid.
} 
dynczo stały wysokie stoły z białymi obrusami, związane u dołu złotymi kokardami, w małe wazy na stołach wetknięte były lilie, obok nich stały ciasteczka i suszone owoce, a na długim stole rozstawione były czerwone wino i kawa. Rozmawiający goście krążyli między wysokimi stołami, małe roboty woziły na swoich głowach tace, zbierając puste kieliszki po winie. [...]

— Tych dań nie sprzedaje się na zewnątrz, więc nie mają ceny. Ja też nie wiem, ile kosztują — Lao Ge zaczął jeść pałeczkami. — Nic specjalnego. Kosztuje jakoś dziesięć, dwadzieścia tysięcy, niektóre może trzydzieści albo czterdzieści. Jakoś tak ${ }^{49}$.

Struktura fabularna „Składającego się Pekinu” bazuje na opozycji przestrzennej - kontrasty między poszczególnymi Przestrzeniami i stylami życia ich mieszkańców wysuwają się na pierwszy plan, wyraźnie zarysowując wizję podzielonego Pekinu przyszłości — podzielonego nie tylko fizycznie, ale także społecznie. Mieszkańcy każdej z trzech Przestrzeni nie tylko mają do dyspozycji różne powierzchnie życiowe, dostępny im czas także poddany jest regulacji i odgórnie reglamentowany.

Symbolika opowiadania opiera się głównie na metaforze przestrzeni, która ciągnie się przez całą treść utworu. „Rozwarstwienie” Pekinu staje się metaforycznym przedstawieniem umacniającego się rozwarstwienia społecznego i skrajnie różnych warunków, w jakich żyją ludzie. Zhang Jing (张婧, Zhāng Jìng) w swoim artykule zwraca uwagę, że metaforyczne użycie przestrzeni pojawia się coraz częściej od początków XX wieku w chińskiej literaturze, i wskazuje przy tym na twórczość Lu Xuna (鲁迅, Lǔ Xùn) i Ding Ling (丁玲, Dīng Líng). Podkreśla też, że taki zabieg znacznie podnosi walory artystyczne „Składającego się Pekinu”,

Przestrzeń, w której rozgrywa się akcja opowiadania, jest nieprzyjazna i przytłaczająca, szczególnie dla głównego bohatera. Widać to nie tylko w Trzeciej Przestrzeni, gdzie Lao Dao z trudem przeciska się między stłoczonymi ludźmi, ale także w Drugiej i Pierwszej, gdzie bohater czuje się niepewnie i spodziewa się niebezpieczeństwa, które nadejść może z każdej strony.

Trzy Przestrzenie Pekinu funkcjonują w tej samej przestrzeni, w różnym jednak czasie, składając i rozkładając się na zmianę wedle ustalonego harmonogramu. Przejście z jednej Przestrzeni do drugiej nazywane jest Zmianą i może być obserwowane z zewnątrz, przez ludzi znajdujących się poza szóstą obwodnicą Pekinu:

\footnotetext{
${ }^{49}$ Ibid.

${ }^{50}$ ZHĀNG Jìng, ,Shì zhédié Běijīng háishì zhédié jiāolü? — Tán Běijīng Zhédié de kōngjiān yǐnyù" [Składanie Pekinu czy składanie niepokojów? - o metaforyce przestrzeni w „Składającym się Pekinie”], Míngzuò Xīnshăng [Recenzje Słynnych Dzieł] 35 (2016): 147.
} 
Każdego ranka, jeśli patrzeć z daleka, tak jak kierowcy ciężarówek oczekujący na wjeździe na autostradę, można było dostrzec rozciąganie się i składanie całego miasta. [...] Wczesnym świtem całe miasto składało się, zapadając się ku ziemi. Wieżowce na wzór najbardziej uniżonych sług zgięły się w pół, pokornie pozwalając się przeciąć, aż głowy sięgnęły stóp, przylgnęły blisko do siebie, a potem ponownie przełamały się, zginając w pół, wygięły głowy i ramiona, wciskając je w szczeliny. Wieżowce po zgięciu się połączyły się na nowo, zgromadziły się, tworząc ogromną zbitą kostkę Rubika, ciasno przylegając do siebie, zatopiły się w głęboki sen. Następnie ziemia obróciła się, ziemia kawałek po kawałku obracała się wokół własnej osi o 180 stopni aż na drugą stronę, ukazując drugą warstwę budynków. Budynki rozłożyły się i powstały, na tle szaroniebieskiego nieba przypominały przebudzone zwierzęta. Samotna wyspa miasta zajęła swoją pozycję wśród pomarańczowawej poświaty świtu, rozpostarła się, powstała i wzniosła się pomiędzy szarawymi chmurami ${ }^{51}$.

Podczas Zmiany mieszkańcy Pekinu pogrążeni są w głębokim śnie wywołanym przez użycie gazu usypiającego, bezpiecznie schowani w kapsułowych łóżkach. Wszystkie przedmioty muszą być zabezpieczone, by nie uległy uszkodzeniu w trakcie składania się i rozkładania budynków, co zostaje opisane przy scenie opuszczania Peng Li przez Lao Dao. Zmiana, która oddziela od siebie poszczególne Przestrzenie, staje się prawie niemożliwą do przebycia barierą fizyczną oddzielającą od siebie mieszkańców Pekinu i staje się metaforą nieprzekraczalnych barier społecznych, pogłębiającego się rozwarstwienia społecznego oraz petryfikacji systemu klasowowarstwowego. Awans społeczny nie jest niemożliwy (przykładem jest Lao Ge, któremu udało się zamieszkać w Pierwszej Przestrzeni), jest jednak w zasadzie dla większości nieosiągalny, a różnice między mieszkańcami Pierwszej i Trzeciej Przestrzeni są szczególnie widoczne. Główny bohater zwraca na nie uwagę podczas swojego powrotu z wyprawy, kiedy jest świadkiem kłótni dwóch młodych kobiet, A Bei (阿贝, Ā Bèi) i Lan Lan (阑 阑, Lán Lán), ze zbierającą czynsz nadzorczynią budynku:

Chciał sprawić, by A Bei nie awanturowała się, zapomniała o tych drobnostkach, żeby tylko przestała się awanturować. Chciał jej powiedzieć, że dziewczęta powinny elegancko siedzieć, z kolanami zakrytymi przez spódniczkę, delikatnie się uśmiechać, pokazując śliczne zęby, mówić łagodnym tonem, dopiero wtedy były uwielbiane przez ludzi. Wiedział jednak, że one nie tego potrzebowały ${ }^{52}$.

\footnotetext{
${ }^{51}$ HǍO, „Běijīng Zhédié”.

${ }^{52}$ Ibid.
} 
Następnie Lao Dao przekazuje nadzorczyni banknot o nominale dziesięciu tysięcy yuanów i bez słowa wraca do swojego mieszkania. Scena ta podkreśla różnice między mieszkańcami różnych przestrzeni, ich codziennością - ci, mieszkający w Trzeciej Przestrzeni z trudem zaspokajają najbardziej podstawowe potrzeby, z kolei ci z Pierwszej Przestrzeni mają wszystkiego pod dostatkiem. Opis nawiązuje do spotkanej wcześniej Yi Yan, kobiety pełnej gracji i elegancji. To właśnie po to, by zapewnić swojej adoptowanej córce taką przyszłość, Lao Dao zdecydował się na niebezpieczną eskapadę.

Proces metamorfozy, przez którą przechodzi Pekin co kilka lub kilkanaście godzin, został opisany też z perspektywy próbującego przedostać się między Przestrzeniami Lao Dao:

Dostrzegł szczelinę w trawniku, to właśnie było miejsce obrotu. Nim jeszcze tam dobiegł, usłyszał zza siebie stłumiony rumor i pojedyncze głośne trzaski. Lao Dao obrócił głowę, wieżowiec składał się w pół, górna połowa właśnie zginała się ku ziemi, naciskając powoli, ale nieubłaganie. [...] Zmiana się rozpoczęła. To był cykl podziału powtarzany co dwadzieścia cztery godziny. Cały świat zaczynał się obracać. Dźwięk zginających się stalowych belek i cegieł zlał się w jedno, przypominając zepsutą linię produkcyjną. Wieżowce scalały się ze sobą, składały, formując sześciany. Neonowe lampy, szyldy sklepowe, balkony i inne pomocnicze struktury, wszystkie zostały pochłonięte przez ściany, przypominając przyklejoną do budynków skórę. Wszystkie struktury były wykorzystywane, każdy cal przestrzeni został wypełniony. [...] Podłoże wzniosło się. Lao Dao obserwował kierunek przemieszczania się powierzchni, dotarł do skraju, a potem wraz z podnoszącą się krawędzią wspinał się nieustannie coraz wyżej. Wspinał się, używając zarówno dłoni, jak i stóp, od marmurowej krawędzi, przez ziemistą powierzchnię, łapiąc się wystających z niej kawałków metalu, na początku kierując się w dół, szukając stopami zagłębień, szybko, wraz z obrotem całego kawałka ziemi został wyniesiony do góry ${ }^{53}$.

W opowiadaniu Hao Jingfang Pekin staje się bezdusznym molochem, miastem, które więzi wszystkich mieszkańców w nieustannej zmianie i metamorfozie. Życie pekińczyków jest podporządkowane nieustającemu cyklowi składania i rozkładania się metropolii. Tylko władze miasta, reprezentowane przez bezimiennego siwowłosego starszego mówcę, mają wpływ na Zmianę i mogą ją regulować. Bezimienny mówca wydaje się mieć na uwadze dobro wszystkich mieszkańców — także tych z Trzeciej Przestrzeni — staje w opozycji do projektu robotyzacji pracy przedstawionego przez Wu Wena, który pozbawiłby pracy wszystkich zajmujących się segregacją i przetwórstwem śmieci.

\footnotetext{
${ }^{53}$ Ibid.
} 
Problemy ekonomiczne i społeczne, które niosą z sobą postęp technologiczny i robotyzacja, są poruszone również podczas rozmowy Lao Dao z Lao Ge. Ten drugi zwraca uwagę na kwestię tańszych kosztów produkcji przy zastosowaniu robotów oraz bezrobocia spowodowanego ich wykorzystaniem. Zarządcy Pekinu wykorzystali następujące rozwiązanie problemu zastoju ekonomicznego: „najlepszym sposobem jest gruntowne zmniejszenie czasu części ludzi poświęcanego na życie i znalezienie dla nich jakiegoś zajęcia. Rozumiesz? Wciśnięcie ich w noc. To ma jeszcze jedną zaletę, inflacja nie dociera na dół [...] PKB rośnie [...]. Ludzie w ogóle niczego nie zauważają"54.

Miasto pozostające w nieustannej metamorfozie może być odczytane nie tylko jako metafora rozwarstwienia społecznego, ale także jako metafora technologii, która coraz bardziej rozdziela od siebie ludzi oraz czyni ich zbędnymi. Symbolizować może także bezduszny system napędzany postępem technologicznym, co widoczne jest podczas próby przejścia Lao Dao z Pierwszej Przestrzeni z powrotem do Drugiej — ze względu na opóźnienia i niedopatrzenia Zmiana zostaje opóźniona i zatrzymana, i cofnięta w połowie przebiegu, przez co główny bohater zostaje niemal zgnieciony i uwięziony między dwoma krawędziami złożonej szczeliny.

Gdy główny bohater pozostaje uwięziony, zdaje sobie sprawę ze swojej bezsilności, jak również z tego, że z punktu widzenia systemu jest nieistotny. „W liczbie 512800000 był jedynie najbardziej pospolitą jednostką [...], przypominał nigdy nieistniejący błąd statystyczny, nie liczył się zupełnie jak pył" ${ }^{\prime 5}$. Scena ta podkreśla bezradność pojedynczego człowieka w stosunku do postępu technologicznego, który zdaje się odbierać ludziom prawo do życia i istnienia. W „Składającym się Pekinie” żadna z postaci nie jest przedstawiona jako zła i nikt nie staje się przeciwnikiem dla głównego bohatera, jedyną przeszkodą $\mathrm{w}$ jego podróżach jest bezosobowe i nieogarnięte miasto-moloch, tłamszące i duszące swoim ogromem. Ani Lao Dao, ani żaden inny bohater nie buntuje się przeciwko niemu, wszyscy trwają na swoich pozycjach, co najwyżej obawiając się o swoje życie i przyszłość. Główny bohater nie ma ani środków, ani chęci by walczyć z systemem — jego jedynym pragnieniem i nadzieją jest zapewnienie szansy na lepszy los swojej adoptowanej córce, Tangtang. Lao Dao może więc być uznany za przedstawiciela tych wszystkich, którzy nie nadążają za postępem technologicznym, którzy są przez niego uznani za zbędnych i którzy sami nie mają szans na wyrwanie się z biedy, a ich jedyna nadzieja leży w potomstwie.

\footnotetext{
${ }^{54}$ Ibid.

${ }^{55}$ Ibid.
} 
„Składający się Pekin” czerpie z wielu tematów i gatunków literackich i nie daje się łatwo zamknąć w określonych ramach. Wykorzystuje nie tylko elementy science fiction, jak na przykład umiejscowienie akcji, zaawansowane technologie czy też popularny motyw utopii. Statyczni bohaterowie i zastosowanie czasu mitycznego (cyklicznego, wyznaczonego nie porami roku, a rozkładaniem się Pekinu) nawiązują do baśni. Bardzo blisko jest też opowiadaniu do przypowieści - wskazują na to schematyczne postaci, uproszczona fabuła oraz obecność symboli. Można więc nazwać „Składający się Pekin" utopijną przypowieścią science fiction, ponieważ pod maską opowiadania science fiction i przy wykorzystaniu utopijnej wizji przyszłości stara się przy użyciu metafor przedstawić zagubienie i niepewność współczesnego człowieka w obliczu nowoczesnych technologii.

\section{BIBLIOGRAFIA}

BAKER, Brian. Science Fiction. London: Palgrave, 2014.

BAL, Mieke. Narratologia. Wprowadzenie do teorii narracji. Przekład zespołowy pod redakcją Ewy Kraskowskiej i Ewy Rajewskiej. Seria: Eidos. Kraków: Wydawnictwo Uniwersytetu Jagiellońskiego, 2012.

BAUdRILlARD, Jean. Symulakry i symulacja. Przełożył Sławomir Królak. Warszawa: Sic! 2005.

CHÉN Róng. „Běijīng zhédié: Huídào yuándiăn de lüxíng” [,Składający się Pekin”: podróż powrotna do punktu wyjścia]. Xīndōngfāng Yīngyǔ [Angielski Nowoorientalny] 11 (2016): 3840. 陈蓉. 《北京折叠》：回到原点的旅行 “新东方英语” 11 (2016): 38-40。

CHEN Qiufan. „The Torn Generation: Chinese Science Fiction in a Culture in Transition” [Rozdarte pokolenie: chińskie science fiction w kulturze w fazie przejściowej]. W: KEN Liu. Invisible Planets. An Anthology of Contemporary Chinese Science Fiction [Niewidzialne Planety. Antologia współczesnej chińskiej science fiction], 369-375. London: Head Zeus 2016.

HǍI Xīn. „Hăojǐngfāng de shìjiè-xiànshí zhōngguó de kēhuàn “liúpài'” [Świat Hao Jingfang „nurt” współczesnego chińskiego science fiction]. Qílǔ Zhōukān [Tygodnik Qilu] 2016, 29: 72-74. 海欣: 郝景芳的世界一现实中国的科幻“流派”, 齐鲁周刊” 2016, 29: 72-74。

HăO Jǐngfāng. „Běijīng Zhédié” [Składający się Pekin]. Dostęp 12.06.2017. http://jessica-hjf. lofter.com/post/1d118899_60d4821?act=qbbloglofter_20150506_01. 郝景芳. 北京折叠。

HuA Yan. „Gothic Elements in Folding Beijing” [Elementy gotyckie w Składającym się Pekinie]. Academics 11 (2016): 277-282.

JAHN, Manfred. „Narratology: A guide to the Theory of Narrative” [Narratologia: Przewodnik teorii narracji]. Dostęp 12.06.2017. http://www.uni-koeln.de/\%7Eame02/pppn.htm [wersja: 2.0., May 2017].

James, Edward, i Farah Mendlesohn. The Cambridge Companion to Science Fiction [Niezbędnik Cambridge do science fiction]. New York: Cambridge University Press, 2003.

Ken Liu. Invisible Planets. An Anthology of Contemporary Chinese Science Fiction [Niewidzialne Planety. Antologia współczesnego chińskiego science fiction]. London: Head Zeus, 2016. 
LIU Cixin. „The Worst of All Possible Universes and the Best of All Possible Earths: Three-Body and Chinese Science Fiction" [Najgorszy z możliwych wszechświatów i najlepsza z możliwych Ziemi: Trzy Ciała oraz chińskie science fiction]. W: KeN Liu. Invisible Planets. An Anthology of Contemporary Chinese Science Fiction [Niewidzialne Planety. Antologia współczesnej chińskiej science fiction], 361-367. London: Head Zeus, 2016.

MǍ Yǔhuá. „Běijīng zhédié: zhōngguóhuà kēhuàn de xùshì yǔ xiànshí” [„Składający się Pekin”: narracja i rzeczywistość science fiction w chińskim stylu]. Chūbăn Guăngjiăo [Szeroki Przegląd Publicystyczny] 2016, 276: 92-94. 马予华. 《北京折叠》: 中国化科幻的叙事与现实 ,出版广角” 2016, 276: 92-94。

Nodelman, Perry. „The Cognitive Estragement of Darko Suvin” [Defamiliaryzacja kognitywna Darko Suvina]. Children's Literature Association Quaterly [Kwartalnik Stwowarzyszenia Literatury Dziecięcej] 1981, nr 5, z. 4: 24-27.

ORAmus, Dominika. O pomieszaniu gatunków. Science fiction a postmodernizm. Warszawa: Wydawnictwo „Trio”, 2010.

RÈN Dōngméi. „Cóng kēhuàn xiànshí zhǔyì jiăodù jiědú Běijīng Zhédié” [Odczytanie „Składającego się Pekinu” z punktu widzenia realizmu science fiction]. Nánfāng Wéntán [Południowe Forum Literatury] 6 (2016): 46-49. 任东梅: 从科幻现实主义角度解读《北京折叠》, 南方 文坛” 6 (2016): 46-49。

„Science Fiction in China: 2016 in Review” [Science fiction w Chinach: przegląd roku 2016]. Amazing Stories. Dostęp 12.06.2017. http://amazingstoriesmag.com/2017/02/science-fictionin-china-2016-in-review/

SEED, David. Science Fiction: A very short introduction [Science fiction. Bardzo krótkie wprowadzenie]. New York: Oxford University Press, 2011. DOI: 10.1093/actrade/9780199557455. 001.0001

YÁNG Yànjiā. „Rénlèi zhōngxīn shénhuà de jiěgòu—lùn zhōngguó xīnshēngdài kēhuàn xiăoshuō tèzhēng zhī yî̀" [Dekonstrukcja mitu antropocentryzmu — o jednej z cech Nowego Pokolenia chińskiego science fiction]. Guăngdōng Jishù Shīfàn Xuéyuàn Xuébào [Czasopismo Guandong Normal University] 4 (2011): 90-92. 杨燕佳: 人类中心”神话的解构一一论中国新生 代科幻小说特征之一,广东技术师范学院学报” 4 (2011): 90-92。

WÚ Yán. „Lùn kēhuàn xiăoshuō de găiniàn” [O pojęciu science fiction]. Kūnmíng Shīfàn Gāoděng Zhuănkē Xuéxiào Xuébào [Czasopismo Uniwersytetu Kunming] 26 (2004): 5-9. 吴岩: 论科幻小说的概念, 昆明师范高等转科学校学报” 26 (2004): 5-9。

XIA Jia. „What Makes Chinese Science Fiction Chinese?” [Co czyni chińskie science fiction chińskim?]. W: Ken Liu. Invisible Planets. An Anthology of Contemporary Chinese Science Fiction [Niewidzialne Planety. Antologia współczesnego chińskiego science fiction]. London: Head Zeus, 2016.

Xú Gāng. „Xīn shìjì zhōngguó. Kēhuàn wénxué de liúbiàn” [Chiny w nowym wieku. Ewolucja literatury science fiction]. Yuèhăifēng [Wieści z Guandong-Hainanu] 6 (2011): 47-53. 徐刚: 新世纪中国。科幻文学的流变, 粤海风” 6 (2011): 47-53。

ZHĀNG Jìng. „Shì zhédié Běijīng háishì zhédié jiāolü? — Tán Běijīng Zhédié de kōngjiān yǐnyù” [Składanie Pekinu czy składanie niepokojów? - o metaforyce przestrzeni w „Składającym się Pekinie”]. Míngzuò Xīnshăng [Recenzje Słynnych Dzieł] 35 (2016): 147-148. 张婧: 是折叠 北京还是折叠焦虑? — 谈《北京折叠》的空间隐喻, 名作欣赏” 35 (2016): 147-148。

ZHĀNG Yuè. „Zhédié de běijīng, sīliè de shèhuì, yīdiăn yě bù kēhuàn” [Składający się Pekin, rozdarte społeczeństwo, ani odrobiny science fiction]. Zhōngguāncūn [Magazyn Zhongguancun] 10 (2016): 119. 


\title{
„TO, CZEGO NIE MOŻNA ZMIENIĆ, MOŻNA JEDYNIE CIERPLIWIE ZNOSIĆ”: „SKŁADAJĄCY SIĘ PEKIN” HAO JINGFANG JAKO METAFORA ROZWARSTWIONEGO SPOŁECZEŃSTWA
}

\author{
Streszczenie
}

Od lat 90. XX wieku w Chinach trwa złoty okres rodzimego science fiction, głównie dzięki temu, że stało się ono dla pisarzy środkiem do wyrażenia wszystkiego, czego nie była w stanie wyrazić literatura głównego nurtu, oraz komentowania nieustannie zmieniającej się teraźniejszości. W artykule zostaje przeanalizowany „Składający się Pekin” — opowiadanie przedstawicielki Nowego Pokolenia chińskiego science fiction, Hao Jingfang, które w 2016 r. zdobyło nagrodę Hugo. Wykreowany przy użyciu metod charakterystycznych dla science fiction oraz metaforyce przestrzeni obraz Pekinu z przyszłości jest refleksją nad problemami współczesności, takimi jak nieprzekraczalność barier społecznych, spetryfikowany system klasowo-warstwowy czy też rozwój technologiczny, który czyni ludzi zbędnymi. Opowiadanie może być odczytane jako utopijna przypowieść science fiction, która dzięki rozbudowanej metaforze rozwarstwionego społeczeństwa, uwięzionego w stanie nieustannej zmiany i bezosobowym mieście-molochu, ostrzega przed możliwą ponurą przyszłością, ale przede wszystkim wyraża zagubienie i niepewność współczesnego człowieka w obliczu ciągle zmieniającej się postmodernistycznej rzeczywistości i nowoczesnej technologii.

Słowa kluczowe: Hao Jingfang; Składający się Pekin; Beijing Zhedie; science fiction; fantastyka naukowa; utopia; współczesna literatura chińska.

\section{“THINGS IN LIFE WE CAN'T CHANGE, WE CAN ONLY ACCEPT AND ENDURE": HAO JINGFANG'S “FOLDING BEIJING” AS METAPHORE FOR CLASS-RIDDEN SOCIETY}

\section{S u m m a r y}

The "golden age" of science fiction has lasted since the 90s, mostly due to the fact that science fiction has become a means for writers to express everything what the so-called pure literature was unable to express, and to comment on the ever-changing present reality. In this article, a short novella written by an author representing New Generation of Chinese science fiction Hao Jingfang — "Folding Beijing" - which won the Hugo prize in 2016, is analyzed. Created with the use of methods typical for science fiction, as well as space-metaphor, the vision of a future Beijing becomes a commentary on modern-day problems such as the impassable social barriers, the petrificated social class structure, or the technological development, which renders people useless. The novella may be understood as a utopian science fiction parable, which thanks to the elaborate metaphor of the class-ridden society trapped both in the state of never-ending change and a faceless monstrous metropolis, warns about the possibility of a grim future, but above all else expresses anxieties and insecurities of a modern human facing the ever-changing postmodern reality and advanced technology.

Key words: Hao Jingfang; Folding Beijing; Beijing Zhedie; science fiction; science fantasy; utopia; contemporary Chinese literature. 